\title{
Segmental Bronchoprovocation in Allergic Rhinitis Patients Affects Mast Cell and Basophil Numbers in Nasal and Bronchial Mucosa
}

\author{
GERT-JAN BRAUNSTAHL, SHELLEY E. OVERBEEK, WYTSKE J. FOKKENS, ALEX KLEINJAN, ALAN R. McEUEN, \\ ANDREW F. WALLS, HENK C. HOOGSTEDEN, and JAN-BAS PRINS
}

Departments of Otorhinolaryngology and Pulmonary Medicine, Erasmus University Medical Center Rotterdam, The Netherlands; and Immunopharmacology Group, Southampton General Hospital, Southampton, United Kingdom

\begin{abstract}
Mast cells and basophils are cells that play an important role in the initiation and control of allergic inflammation in asthma and rhinitis. This study was undertaken to determine the presence and dynamics of mast cells and basophils in the nasal and bronchial mucosa of allergic rhinitis patients after segmental bronchial provocation (SBP). Eight nonasthmatic, grass pollen-allergic rhinitis patients and eight healthy controls were included. Bronchial and nasal biopsies, as well as blood samples, were taken before $\left(T_{0}\right)$ and $24 \mathrm{~h}\left(T_{24}\right)$ after SBP. Immunohistochemical staining was performed for mast cells (tryptase and chymase; phenotypes $\mathrm{MC}_{\mathrm{T}}, \mathrm{MC}_{\mathrm{TC}}, \mathrm{MC}_{\mathrm{C}}$ ) and basophils (BB1). In the bronchial mucosa, the number of $\mathrm{BB}^{+}$cells increased significantly $(p<0.05)$ in allergic rhinitis patients after SBP. In the nasal mucosa, the numbers of $\mathrm{MC}_{\mathrm{C}}$ and $\mathrm{MC}_{\mathrm{TC}}$ cells decreased significantly, whereas the numbers of $\left[\mathrm{BB}^{+}\right]$cells increased significantly in allergic rhinitis patients after SBP $(p<0.05)$. In blood, the number of basophils decreased $(p<0.05)$ and the level of interleukin (IL)-5 increased $(p<0.05)$ in atopic patients after SBP. No significant changes could be observed in healthy controls. This study shows that SBP in nonasthmatic allergic rhinitis patients reduces numbers of mast cells in the nose as a result of enhanced degranulation. At the same time, there is evidence for an influx of basophils from the blood into the nasal and bronchial mucosae.
\end{abstract}

Keywords: bronchoprovocation; asthma; rhinitis; biopsy; inflammation

Asthma and rhinitis, which are considered manifestations of the atopic syndrome, often coexist $(1,2)$ and share a common genetic background (3). Although several studies have demonstrated that asthma and rhinitis are characterized by a similar inflammatory process (4-7), pathophysiologic interactions between upper and lower airways are not entirely understood. It is clear that the condition of the upper airways influences the lower airways. In allergic rhinitis patients without bronchial hyperreactivity (BHR), signs of allergic inflammation of the lower airways have been found in induced sputum, bronchoalveolar lavage fluid (BALF), and bronchial biopsy specimens (8-10).

Mast cells and basophils are metachromatically staining cells that are believed to play an important role in the initiation and control of upper and lower respiratory allergy (11). Both cell types express high-affinity receptors for $\operatorname{IgE}(\mathrm{Fc} \varepsilon \mathrm{RI})$. Binding of IgE and subsequent crosslinking of FceRI lead to degranulation of mast cells and release of histamine and proteases, among other effects, characteristic of the early phase of the allergic immune response (EAR). Mast cells are also sources of interleukin (IL)-4, IL-5, IL-6, and tumor necrosis factor

(Received in original form June 16, 2000 and in revised form February 16, 2001) Supported by a grant from the Dutch Asthma Foundation.

Correspondence and requests for reprints should be addressed to G.J. Braunstahl, M.D., Department of Pulmonary Medicine, H-Ee-22.63, EMCR, Dr. Molewaterplein 50, 3015 GE Rotterdam, The Netherlands. E-mail: gj.braunstahl@wanadoo.nl Am J Respir Crit Care Med Vol 164. pp 858-865, 2001

Internet address: www.atsjournals.org
(TNF)- $\alpha$ (12). Through the release of mediators, mast cells can clearly orchestrate the infiltration of leukocytes into sites of mast cell activation (13). Although basophils comprise a minor component of the inflammatory cell influx, they are capable of producing more IL-4 and IL-13 per cell than any other cell type $(14,15)$. Therefore, basophils are considered important modulators of the allergic immune response. Moreover, their total number and relative contribution increase during the late phase of the allergic response (LAR), and correlate with the severity of disease (16). The pattern of mediator release, particularly the lack of a secondary increase in prostaglandin $\mathrm{D}_{2}$ and the corticosteroid sensitivity of the LAR (17), indicates that the basophil and not the mast cell is the main source of histamine in the LAR. An increase in the number of basophil-like cells in the nasal mucosa has been reported after nasal allergen provocation $(18,19)$. In a previous article, we demonstrated that eosinophils, IL- $5^{+}$, and eotaxin ${ }^{+}$cells are increased in the nasal mucosa of AR patients at $24 \mathrm{~h}$ after segmental bronchial provocation (SBP). This indicates that a simultaneous LAR may take place in other organs than those exposed to the allergen (20). Here we report on the contribution of metachromatic cells to the inflammatory process in both the challenged lung and in the nose, with special emphasis on early allergic events. Bronchial and nasal mucosal biopsy specimens and peripheral blood samples were taken from a group of nonasthmatic rhinitis patients with an isolated grass pollen allergy after SBP at a time other than the grass pollen season. The presence of mast cells was established after immunohistochemical double staining for tryptase and chymase (phenotypes $\mathrm{MC}_{\mathrm{T}}, \mathrm{MC}_{\mathrm{TC}}, \mathrm{MC}_{\mathrm{C}}$ ). The presence of basophils was assessed with a novel monoclonal antibody, BB1, which recognizes a unique granule constituent of basophils (21).

\section{METHODS}

\section{Subject Groups}

Eight nonasthmatic allergic rhinitis patients (two men and six women, age range 21 to $31 \mathrm{yr}$ ) and eight nonallergic healthy controls (four men and four women, age range 18 to $29 \mathrm{yr}$ ) were included in the study. Subject characteristics are shown in Table 1 . The rhinitis patients had a history of isolated grass pollen allergy for at least $2 \mathrm{yr}$, as confirmed by a positive skin-prick test reaction to grass pollen extract alone (Vivodiagnost; ALK Benelux BV, Groningen, The Netherlands) and not to a panel of 13 other common allergens. The control subjects had no symptoms or signs of rhinitis and had negative skinprick tests. None of the allergic rhinitis patients or controls had a clinical history of asthma. All had a normal $\mathrm{FEV}_{1}$ and a provocative concentration of methacholine causing a $20 \%$ decrease in $\mathrm{FEV}_{1}\left(\mathrm{PC}_{20}\right.$ methacholine) $>8 \mathrm{mg} / \mathrm{ml}$. Methacholine was administered according to a standardized tidal breathing method (22). None of the subjects smoked or used any medication known to influence the results of the study. Biopsy specimens were obtained between February and April 1998, before the grass pollen season. None of the patients or control subjects had an infection of the respiratory tract or any nasal complaints during the $4 \mathrm{wk}$ preceding the allergen challenge. All partici- 
TABLE 1. SUBJECT CHARACTERISTICS AT BASELINE

\begin{tabular}{|c|c|c|c|c|c|c|c|c|}
\hline Patient & $\begin{array}{l}\text { Age } \\
(y r)\end{array}$ & Sex & $\begin{array}{c}\mathrm{FEV}_{1} \\
(L)\end{array}$ & $\begin{array}{l}\mathrm{FEV}_{1} \\
(\%)\end{array}$ & $\begin{array}{l}\text { IVC } \\
(L)\end{array}$ & $\mathrm{FEV}_{1} / \mathrm{VC}$ & $\begin{array}{c}\mathrm{BAR}^{*} \\
(\%)\end{array}$ & $\begin{array}{c}\mathrm{PC}_{20} \\
(\mathrm{mg} / \mathrm{ml})\end{array}$ \\
\hline \multicolumn{9}{|c|}{ Allergic rhinitis } \\
\hline 1 & 31 & $\mathrm{~F}$ & 4.00 & 108 & 4.99 & 80 & 102 & 40 \\
\hline 2 & 21 & $\mathrm{M}$ & 4.02 & 85 & 5.15 & 79 & 107 & 11.8 \\
\hline 3 & 25 & $\mathrm{~F}$ & 4.74 & 126 & 5.62 & 84 & 102 & 23.6 \\
\hline 4 & 25 & $\mathrm{M}$ & 4.35 & 94 & 5.44 & 80 & 104 & 40 \\
\hline 5 & 27 & $\mathrm{~F}$ & 3.71 & 114 & 4.06 & 91 & 100 & 40 \\
\hline 6 & 23 & $\mathrm{~F}$ & 3.91 & 113 & 4.54 & 86 & 104 & 40 \\
\hline 7 & 23 & $\mathrm{~F}$ & 4.00 & 122 & 4.65 & 86 & 105 & 40 \\
\hline 8 & 21 & $\mathrm{~F}$ & 4.06 & 111 & 4.7 & 86 & 100 & 40 \\
\hline \multicolumn{9}{|l|}{ Controls } \\
\hline 9 & 23 & $\mathrm{~F}$ & 2.96 & 82 & 3.43 & 86 & 110 & 40 \\
\hline 10 & 29 & $\mathrm{M}$ & 5.59 & 115 & 7.42 & 76 & 108 & 32.4 \\
\hline 11 & 24 & $\mathrm{M}$ & 4.14 & 94 & 4.72 & 88 & 101 & 40 \\
\hline 12 & 28 & $\mathrm{~F}$ & 2.52 & 80 & 2.67 & 95 & 102 & 40 \\
\hline 13 & 25 & $\mathrm{~F}$ & 4.21 & 112 & 4.72 & 89 & 101 & 40 \\
\hline 14 & 21 & $\mathrm{M}$ & 5.99 & 100 & 6.98 & 86 & 102 & 40 \\
\hline 15 & 20 & $\mathrm{M}$ & 4.81 & 114 & 5.44 & 88 & 102 & 9 \\
\hline 16 & 18 & $\mathrm{~F}$ & 3.83 & 111 & 5.12 & 76 & 107 & 40 \\
\hline
\end{tabular}

Definition of abbreviations: BAR = beta-agonist response (terbutaline 1,000 $\mu \mathrm{g}$, data are presented as percentage improvement compared to initial value). a virtual value of 40 was assigned to subjects who did not reach a $\mathrm{PC}_{20}$ with $38 \mathrm{mg} / \mathrm{ml}$ methacholilne; IVC = inspiratory vital capacity.

pants gave informed consent to the study, which was approved by the Medical Ethics Committee of the Erasmus Medical Center Rotterdam.

\section{Experimental Design}

The study design is outlined in Table 2. Baseline nasal and bronchial biopsy specimens were collected from patients and controls just before SBP $\left(\mathrm{T}_{0}\right)$. Nasal biopsy specimens were obtained at $1 \mathrm{~h}\left(\mathrm{~T}_{1}\right)$ and $24 \mathrm{~h}\left(\mathrm{~T}_{24}\right)$ after SBP. Collection of bronchial biopsy specimens was repeated $24 \mathrm{~h}$ after SBP $\left(\mathrm{T}_{24}\right)$. Signs and symptoms were scored at the beginning of each visit (at $\mathrm{T}_{0}$ and $\mathrm{T}_{24}$ ) on a $10-\mathrm{cm}$ visual analogue scale (VAS). Symptoms were divided into nasal and ocular complaints (rhinorrhea, watery eyes, nasal itching, sneezing, and nasal blockage) and pulmonary complaints (wheezing, coughing, shortness of breath, and decreased exercise tolerance). Upper and lower airway obstruction were measured through peak nasal inspiratory flow (PNIF) and $\mathrm{FEV}_{1} . \mathrm{FEV}_{1}$ was determined at $\mathrm{T}_{0}, \mathrm{~T}_{1}$, and $\mathrm{T}_{24}$. PNIF was measured with a Youlten peak nasal inspiratory flow meter (Armstrong Industries, Inc., Northbrook, IL) at $\mathrm{T}_{0}$ and $\mathrm{T}_{24}$. Blood samples were taken at $T_{0}$ and $T_{24}$. The basophil percentage of total white blood cells was determined by hemocytometric differential cell counting (Sysmex NE 8000; Sysmex Corporation, Kobe, Japan). IL-5 was measured in serum with a commercially available enzyme-linked immunosorbent assay (ELISA) kit, following the instructions of the manufacturer (Cytoscreen; BioSource International Inc., Camarillo, CA). The minimal detectable dose of hIL-5 with this assay is $<4 \mathrm{pg} / \mathrm{ml}$, and no cross-reactivity was found with other cytokines.

\section{Bronchial Biopsies and Segmental Allergen Bronchoprovocation}

All bronchial biopsy specimens were taken by the same pulmonary physician (S.E.O.). After intramuscular premedication with atropine

TABLE 2. STUDY DESIGN

\begin{tabular}{llcccccc}
\hline & Time Point & $\begin{array}{c}\text { VAS } \\
\text { Score }\end{array}$ & FEV $_{1}$ & PNIF & $\begin{array}{c}\text { Bronchial } \\
\text { Biopsy }\end{array}$ & $\begin{array}{c}\text { Nasal } \\
\text { Biopsy }\end{array}$ & $\begin{array}{c}\text { Blood } \\
\text { Samples }\end{array}$ \\
\hline $\mathrm{T}_{0}$ & Baseline & $\mathrm{x}$ & $\mathrm{x}$ & $\mathrm{x}$ & $\mathrm{x}$ & $\mathrm{x}$ & $\mathrm{x}$ \\
$\mathrm{T}_{1}$ & $1 \mathrm{~h}$ after SBP* & & $\mathrm{x}$ & & & $\mathrm{x}$ & \\
$\mathrm{T}_{24}$ & $24 \mathrm{~h}$ after SBP & $\mathrm{x}$ & $\mathrm{x}$ & $\mathrm{x}$ & $\mathrm{x}$ & $\mathrm{x}$ & $\mathrm{x}$ \\
\hline
\end{tabular}

Definition of abbreviations: PNIF = peak nasal inspiratory flow; SBP = segmental bronchial provocation; VAS = visual analogue scale for scoring nasal and pulmonary symptoms.
$(0.5 \mathrm{mg})$, oropharyngeal anesthesia was accomplished with topical xylocaine spray $1 \%$. The vocal cords, trachea, and bronchial tree were then anesthetized with oxybuprocaine. A fiberoptic bronchoscope was introduced into the airway via the oral route, and mucosal biopsy specimens were taken from the carina of the left upper and lower lobes. Subsequently, SBP was accomplished with a method described previously (20). The tip of the bronchoscope (Model BF, type P20 D; Olympus Optical, Tokyo, Japan) was wedged in the anterior segment of the right upper lobe (RUL), and $10 \mathrm{ml}$ of $0.9 \%$ sterile saline was instilled as a control challenge. Following the control challenge, the bronchoscope was wedged in a segmental bronchus of the right middle lobe (RML) and allergen challenge was achieved by instilling 100 $\mathrm{BU}$ of grass-pollen extract (Vivodiagnost) made up in $5 \mathrm{ml}$ of sterile saline. The challenged site was observed for $5 \mathrm{~min}$. In the absence of local bronchoconstriction, a further $400 \mathrm{BU}$ of allergen in $5 \mathrm{ml}$ of saline was administered, after which the bronchial segment was observed for a further $5 \mathrm{~min}$. The bronchoscope was then quickly removed. After $24 \mathrm{~h}$, each subject underwent a repeat bronchoscopy, during which biopsy specimens were taken from lobar segments of the unchallenged left side, the saline-challenged RUL, and the allergenchallenged RML. The bronchial biopsy specimens were embedded in Tissue-Tek II Optimal Cutting Temperature (OCT) compound (Sakura Finetek USA, Inc., Torrance, CA), frozen, and stored at $-150^{\circ} \mathrm{C}$.

\section{Nasal Biopsies}

All biopsy specimens of nasal mucosa were taken by the same investigator (G.J.B.) according to the study design as shown in Table 2. First, local anesthesia was induced by placing a cotton-wool carrier with 50 to $100 \mathrm{mg}$ of cocaine and 3 drops of epinephrine $(1: 1,000)$ under the inferior turbinate, without touching the biopsy site. Second, mucosal biopsy samples were obtained from the lower edge of the inferior turbinate, about $2 \mathrm{~cm}$ posterior to the edge, by using a Gerritsma forceps with a cup diameter of $2.5 \mathrm{~mm}$. Nasal biopsy specimens were embedded in Tissue-Tek II OCT compound, frozen, and stored at $-150^{\circ} \mathrm{C}(23)$.

\section{Monoclonal Antibodies}

Monoclonal antibodies (mAbs) used in this study were anti-IgE $\left(\operatorname{IgG}_{1}\right.$; $0.2 \mu \mathrm{g} / \mathrm{ml}$; clone HM25M; CLB, Amsterdam, The Netherlands), mouse antibody to human chymase $\left(\mathrm{IgG}_{1} ; 1 \mu \mathrm{g} / \mathrm{ml}\right.$; clone B7; Chemicon, Brunschwig, The Netherlands), mouse antibody to human tryptase $\left(\mathrm{IgG}_{1}\right.$;

TABLE 3. CLINICAL DATA FOR ALLERGIC RHINITIS PATIENTS AND CONTROLS BEFORE $\left(\mathrm{T}_{0}\right)$ AND $24 \mathrm{~h}\left(\mathrm{~T}_{24}\right)$ AFTER SEGMENTAL BRONCHIAL PROVOCATION

\begin{tabular}{|c|c|c|c|c|c|c|c|c|}
\hline \multirow[b]{2}{*}{ Patient } & \multicolumn{2}{|c|}{$\begin{array}{l}\mathrm{FEV}_{1} \\
(L)\end{array}$} & \multicolumn{2}{|c|}{$\begin{array}{l}\text { PNIF } \\
(L)\end{array}$} & \multicolumn{2}{|c|}{$\begin{array}{c}\text { Local } \\
\text { Symptoms }\end{array}$} & \multicolumn{2}{|c|}{$\begin{array}{c}\text { Nose } \\
\text { Symptoms }\end{array}$} \\
\hline & $\mathrm{T}_{0}$ & $\mathrm{~T}_{24}$ & $\mathrm{~T}_{0}$ & $\mathrm{~T}_{24}$ & $\mathrm{~T}_{0}$ & $\mathrm{~T}_{24}$ & $\mathrm{~T}_{0}$ & $\mathrm{~T}_{24}$ \\
\hline \multicolumn{9}{|c|}{ Allergic rhinitis } \\
\hline 1 & 4.00 & 3.82 & 235 & 190 & 6 & 37 & 7 & 56 \\
\hline 2 & 4.02 & 4.05 & 265 & 250 & 26 & 68 & 52 & 128 \\
\hline 3 & 4.74 & 4.34 & 200 & 180 & 0 & 123 & 0 & 35 \\
\hline 4 & 4.35 & 4.21 & 270 & 260 & 36 & 16 & 35 & 35 \\
\hline 5 & 3.71 & 3.35 & 230 & 220 & 24 & 31 & 46 & 54 \\
\hline 6 & 3.91 & 3.94 & 220 & 215 & 13 & 34 & 0 & 47 \\
\hline 7 & 4.00 & 3.77 & 250 & 230 & 10 & 27 & 36 & 49 \\
\hline 8 & 4.06 & 3.64 & 220 & 220 & 8 & 50 & 12 & 28 \\
\hline \multicolumn{9}{|c|}{ Controls } \\
\hline 9 & 2.96 & 2.97 & 120 & 115 & na & na & na & na \\
\hline 10 & 5.59 & 5.13 & 290 & 185 & 28 & 15 & 36 & 53 \\
\hline 11 & 4.14 & 4.10 & 160 & 240 & 4 & 9 & 7 & 6 \\
\hline 12 & 2.52 & 2.46 & 230 & 240 & 31 & 68 & 49 & 203 \\
\hline 13 & 4.21 & 4.08 & 235 & 205 & 7 & 6 & 19 & 63 \\
\hline 14 & 5.99 & 4.69 & 300 & 265 & 8 & 30 & 11 & 43 \\
\hline 15 & 4.81 & 5.68 & 180 & 195 & 21 & 24 & 56 & 53 \\
\hline 16 & 3.83 & 3.62 & 230 & 210 & 3 & 10 & 10 & 17 \\
\hline
\end{tabular}

Definition of abbreviations: $\mathrm{na}=$ not available; PNIF = peak nasal inspiratory flow.

Symptoms were individually expressed in millimeters on a $10-\mathrm{cm}$ visual analogue scale, and a composite score was obtained for nasal complaints (rhinorrhea, watery eyes, nasal itching, sneezing, and nasal discharge) and pulmonary complaints (wheezing, coughing, shortness of breath, and exercise intolerance). 
$0.7 \mu \mathrm{g} / \mathrm{ml}$; clone G3; Chemicon), and antibody to basophilic granules $\left(\mathrm{IgG}_{2 \mathrm{a}},<1 \mu \mathrm{g} / \mathrm{ml}\right.$; clone BB1; Immunopharmacology Group, Southampton General Hospital, Southampton, UK). The mAb BB1 recognizes a unique granule constituent of basophils (21).

\section{Double Staining for Tryptase and Chymase}

Staining was done according to a modified method as previously described (24). Briefly, each tissue specimen was cut into serial 6- $\mu \mathrm{m}$ thick sections on a Reichert-Jung 2800e Frigocut cryostat (Leica, Wetzlaar, Germany) and transferred onto poly-L-lysine-coated slides (Sigma Chemical Co., St. Louis, MO), dried, and stored at $-80^{\circ} \mathrm{C}$. Before staining, slides were heated to room temperature (RT) and subsequently dried and fixed in acetone for $10 \mathrm{~min}$ at RT. Slides were then rinsed in phosphate-buffered saline (PBS; $\mathrm{pH}$ 7.8) and placed in a semiautomatic stainer (Sequenza; Shandon, Sewickley, PA). Endogenous peroxidase was blocked with $0.1 \%$ sodium azide and $0.01 \%$ hydrogen peroxide in PBS for $30 \mathrm{~min}$. Sections were then rinsed in PBS for $10 \mathrm{~min}$, incubated with 10\% normal goat serum (CLB) and 10\% normal rabbit serum (CLB). Subsequently, slides were incubated with mouse antibody to human tryptase for $60 \mathrm{~min}$ at RT. Sections were rinsed with PBS for 5 min, incubated with peroxidase (PO)-conjugated rabbit antimouse (1:200; Sigma) immunoglobulin, rinsed with PBS, and incubated with PO-conjugated mouse anti-PO antibody (1:200; Sigma) for $30 \mathrm{~min}$. Slides were incubated with $10 \%$ normal mouse serum (CLB) for $10 \mathrm{~min}$ and were then incubated with biotinylated mouse antibody to human chymase (B7) for $60 \mathrm{~min}$. They were rinsed once more with PBS for $5 \mathrm{~min}$ and incubated with alkaline phosphatase (AP)-conjugated goat antibiotin antibody (1:50; Sigma) for $30 \mathrm{~min}$. Next, slides were rinsed with PBS for $5 \mathrm{~min}$ and with Tris buffer $(0.1 \mathrm{M}$, $\mathrm{pH}$ 8.5) for $5 \mathrm{~min}$, and were incubated for $30 \mathrm{~min}$ in Fast Blue substrate containing levamisole to block endogenous AP enzyme activity. Sections were then rinsed with sodium acetate $(0.1 \mathrm{M}, \mathrm{pH}$ 4.6) for $5 \mathrm{~min}$ and incubated with aminoethylcarbazole (AEC; $0.05 \%$ in sodium acetate $0.1 \mathrm{M}, \mathrm{pH} 4.6$, and $0.01 \%$ peroxide) substrate for $30 \mathrm{~min}$. Following this, the slides were rinsed with distilled water and mounted in glycerin gelatin. Control staining was done with an irrelevant $\mathrm{mAb}$ of the same subclass and at the same protein concentration as the specific antibody.

\section{Single Staining and Tyramide Signal Amplification}

The mAb stains were developed with the supersensitive immuno-AP (ss-AP) method as previously described (24). The basophil staining method differed from the staining method described earlier in the inclusion of a tyramide signal amplification (TSA) (NEN Inc., Boston, MA) step to enhance the BB1 signal. Briefly, tissue fixation was done as previously described, followed by blocking of endogenous avidin and biotin with the Vector Blocking Kit, (Vector Laboratories, Burlingame, CA) according to the specifications of the manufacturer. Subsequently, slides were rinsed in PBS (5 min) and incubated with BB1 antibody for $1 \mathrm{~h}$. After rinsing in PBS, endogenous peroxidase was blocked with azide $(0.2 \%)$, peroxidase $(0.02 \%)$, and methanol $(50 \%)$ in PBS. TSA was done by subsequent incubation with streptavidin PBS/bovine serum albumin (BSA) solution (1:100) (NEN Inc.) for 10 min, rinsing with PBS, and incubation with AP-conjugated goat antibiotin antibody (1:50, Sigma) for $30 \mathrm{~min}$. This was followed by incubation in new fuchsin (Chroma, Kongen, Germany) substrate (containing levamisole to block endogenous AP enzyme activity) for a maximum of $30 \mathrm{~min}$. The sections were then rinsed in distilled water, counterstained with Gill's hematoxylin, and mounted in glycerin gelatin. Control staining was done with an irrelevant $\mathrm{mAb}$ of the same subclass and at the same protein concentration as the specific antibody.

\section{Microscopic Evaluation}

Biopsy specimens were coded and stained cells in two sections $120 \mu \mathrm{m}$ apart were counted under blind conditions for each antibody. Bronchial sections were divided into epithelium and subepithelium (an area $100 \mu \mathrm{m}$ deep into the lamina propria, along the length of the epithelial basement membrane), and stained cells were counted as previously described (20). Nasal biopsy sections were divided into epithelium, subepithelium, and lamina propria (total subepithelial mucosa). Positively stained epithelial and subepithelial cells were counted along the basement membrane (BM), which had to be undamaged for a length of at least $1 \mathrm{~mm}$ before being accepted for evaluation. For lamina propria, a minimum area of $1 \mathrm{~mm}^{2}$ was required for analysis. Cell numbers in the subepithelial mucosa were determined as the number of immunostained cells per $\mathrm{mm}^{2}$, and those in the epithelium were determined as cells per mm of BM, using an Axioskop 20 microscope (Zeiss, Jena, Germany) with an eyepiece graticule at a magnification of $\times 200$.

\section{Statistical Analysis}

Data were first analyzed with Friedman's test for several related samples. In cases of significance, further analysis was done with Wilcoxon's test for intragroup analysis and the Mann-Whitney U test for intergroup analysis. Data are presented as median \pm range. Correlations were evaluated with Spearman's rank correlation test. A value of $\mathrm{p}<0.05$ was considered significant.

\section{RESULTS}

\section{Clinical Data}

All control subjects and allergic rhinitis patients received a total dose of $500 \mathrm{BU}$ grass pollen solution without exhibiting any macroscopic bronchoconstriction. An overview of the clinical data is given in Table 3. A significant decrease in $\mathrm{FEV}_{1}$ of $9 \%$ (range: $-20 \%$ to $+3 \%$ ) was measured at $\mathrm{T}_{1}$ in the allergic rhinitis group $(\mathrm{p}=0.03)$, whereas in controls, $\mathrm{FEV}_{1}$ barely changed (median: $-1 \%$; range: $-4 \%$ to $+4 \%$ ). At $\mathrm{T}_{24}, \mathrm{FEV}_{1}$ was still $9 \%$ (range: $-11 \%$ to $0 \%$ ) lower than its baseline value in allergic patients, but only $2 \%$ (range: $-9 \%$ to $0 \%$ ) below its baseline value in healthy controls. Although the overall increase in nasal and pulmonary symptoms was greater in the allergic subgroup at $\mathrm{T}_{24}$, no significant differences were found in total nasal and pulmonary VAS scores for allergic rhinitis patients versus controls.
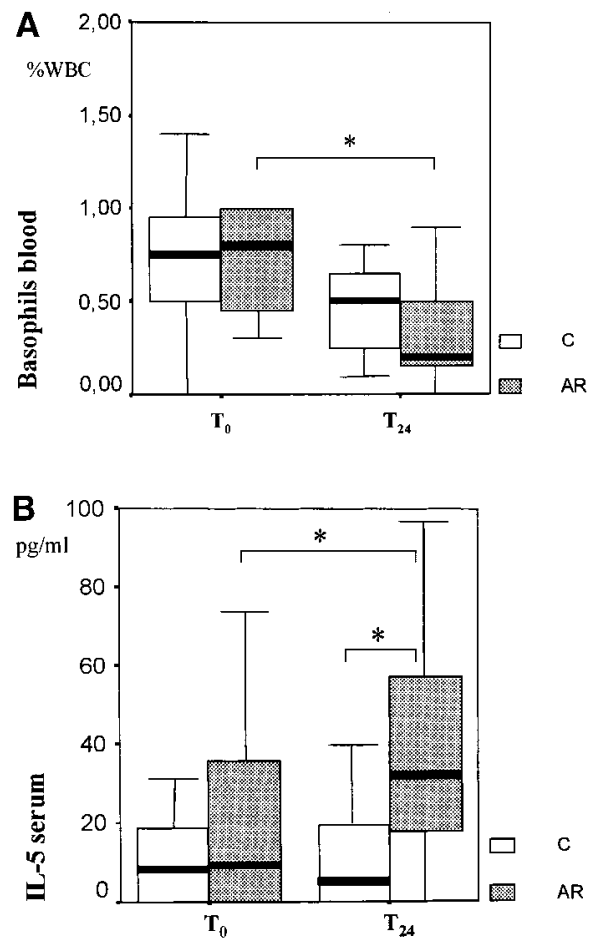

Figure 1. (A) Percentage of peripheral blood basophils in white blood cell $(\mathrm{WBC})$ count before $\left(\mathrm{T}_{0}\right)$ and $24 \mathrm{~h}\left(\mathrm{~T}_{24}\right)$ after SBP. AR = allergic rhinitis patients; $C=$ control subjects. Data are presented as median \pm range. ${ }^{*} \mathrm{p}<0.05$. (B) Concentration of hlL-5 $(\mathrm{pg} / \mathrm{ml})$ in serum before $\left(\mathrm{T}_{0}\right)$ and $24 \mathrm{~h}\left(\mathrm{~T}_{24}\right)$ after SBP. AR = allergic rhinitis patients; $\mathrm{C}=$ control subjects. Data are presented as median \pm range. ${ }^{*} p<0.05$. 


\section{Peripheral Blood Parameters}

No significant difference in baseline blood basophil percentage was observed in allergic patients (median: $0.8 \%$; range: $0.3 \%$ to $2.0 \%$ ) as compared with healthy controls (median: $0.75 \%$; range: $0 \%$ to $1.4 \%$ ). At $\mathrm{T}_{24}$, the percentage of blood basophils was significantly decreased in allergic patients as compared with baseline $(\mathrm{p}=0.02$; Figure 1a). This was accompanied by a smaller reduction in the control group $(\mathrm{p}=0.2)$. No significant difference was found between allergic rhinitis patients and controls at $T_{24}$.

At $\mathrm{T}_{0}$, the concentration of IL-5 in the serum of allergic rhinitis patients (median: $9.6 \mathrm{pg} / \mathrm{ml}$; range: 0 to $73.6 \mathrm{pg} / \mathrm{ml}$ ) was comparable to that of controls (median: $8.3 \mathrm{pg} / \mathrm{ml}$; range: 0 to $31.3 \mathrm{pg} / \mathrm{ml}$ ). At $\mathrm{T}_{24}$, however, the median concentration of IL-5 in allergic rhinitis patients was increased by threefold over the baseline concentration ( $p=0.02$; Figure $1 \mathrm{~b}$ ). The serum concentration of IL-5 in the control group did not change after SBP, and was significantly lower than the serum concentrations of IL-5 in the allergic rhinitis group $(\mathrm{p}=0.05)$.

\section{Immunostaining}

General description. Three nasal mucosa specimens and four bronchial biopsy specimens were collected per patient. Of the 112 biopsy specimens, 106 met the criteria for evaluation. In bronchial biopsy specimens, the median length of evaluable basement membrane was $3.7 \mathrm{~mm}$ (range: 1.1 to $7.8 \mathrm{~mm}$ ). The median surface area of subepithelium was $0.37 \mathrm{~mm}^{2}$ (range: 0.11 to $0.78 \mathrm{~mm}^{2}$ ). Bronchial epithelium and subepithelium could not be evaluated in five samples. In nasal biopsy specimens, the median length of evaluable basement membrane was $5.2 \mathrm{~mm}$ (range: 1.1 to $12.5 \mathrm{~mm}$ ), the median surface area of nasal subepithelium was $0.54 \mathrm{~mm}^{2}$ (range: 0.11 to $1.25 \mathrm{~mm}^{2}$ ), and the median surface area of lamina propria was $4.69 \mathrm{~mm}^{2}$ (range: 1.88 to $8.31 \mathrm{~mm}^{2}$ ). The specified areas could not be evaluated in one case. A minimal number of seven subjects per subgroup could be included for every time point.

Bronchial specimens. At $\mathrm{T}_{0}$, the numbers of $\mathrm{IgE}^{+}, \mathrm{BB}^{+}$, tryptase $^{+}$, and chymase ${ }^{+}$cells (phenotypes $\mathrm{MC}_{\mathrm{T}}, \mathrm{MC}_{\mathrm{TC}}$, and
$\mathrm{MC}_{\mathrm{C}}$ ) in bronchial epithelium and subepithelium were low and not significantly different in the allergic rhinitis patients and controls (Table 4). At neither $\mathrm{T}_{0}$ nor $\mathrm{T}_{24}$ could changes in $\mathrm{IgE}^{+}, \mathrm{MC}_{\mathrm{T}}, \mathrm{MC}_{\mathrm{TC}}, \mathrm{MC}_{\mathrm{C}}$, and $\mathrm{BB} 1^{+}$cells be detected in control subjects in any of the tissues studied. In bronchial epithelium of allergic rhinitis patients, only a few mast cells and $\mathrm{BB} 1^{+}$cells (Figure 2 ) could be detected before and after SBP. At $\mathrm{T}_{24}$, the epithelial $\mathrm{IgE}^{+}$cell number tended to be higher in the unchallenged $(p=0.05)$ and saline challenged $(p=0.1)$ segments, and was significantly higher in the allergen challenged $(\mathrm{p}=0.04)$ segment of allergic rhinitis patients than of controls. At $\mathrm{T}_{24}$, the numbers of $\mathrm{IgE}^{+}$cells and mast cells in the subepithelium of allergic rhinitis patients were not significantly affected. The number of $\mathrm{BB}^{+}$cells in the bronchial subepithelium (Figure 3 ) of allergic rhinitis patients, however, increased significantly in the allergen challenged segment $(\mathrm{p}=$ $0.02)$, saline control segment $(\mathrm{p}=0.02)$, and even in the unchallenged segment $(\mathrm{p}=0.08)$. At $\mathrm{T}_{24}$, the number of $\mathrm{BB} 1^{+}$ cells in the bronchial subepithelium was significantly increased in the allergic rhinitis subjects as compared with the controls for the allergen challenged segment $(\mathrm{p}=0.002)$ and saline challenged segment $(\mathrm{p}=0.01)$, but not for the unchallenged segment $(\mathrm{p}=0.6)$.

Nasal specimens. As in the bronchial mucosa, only few chymase ${ }^{+}$, tryptase $^{+}$(Figure 4 ), or BB1 ${ }^{+}$cells were seen in the nasal epithelium, of any subject either before or after SBP (Table 5). At $\mathrm{T}_{0}, \mathrm{IgE}^{+}$cells could be detected in the nasal epithelium, and the numbers of such cells were higher in the allergic rhinitis patients than in controls $(\mathrm{p}=0.06)$. At $\mathrm{T}_{0}$, the numbers of $\mathrm{IgE}^{+}$cells and $\mathrm{MC}_{\mathrm{TC}}, \mathrm{MC}_{\mathrm{T}}$, and $\mathrm{BB} 1^{+}$cells in the nasal lamina propria showed no significant differences in the allergic rhinitis patients and control subjects. The number of $\mathrm{MC}_{\mathrm{C}}$ cells, however, was higher in the rhinitis patients than in the controls at $\mathrm{T}_{0}(\mathrm{p}=0.03)$.

At $T_{1}$, no significant changes in cell numbers were found for mast cells, $\mathrm{IgE}^{+}$cells, or $\mathrm{BB} 1^{+}$cells in nasal epithelium and lamina propria of the allergic rhinitis patients as compared

TABLE 4. CELL NUMBERS IN BRONCHIAL SPECIMENS BEFORE $\left(T_{0}\right)$ AND $24 \mathrm{~h}\left(\mathrm{~T}_{24}\right)$ AFTER SEGMENTAL BRONCHIAL PROVOCATION

\begin{tabular}{|c|c|c|c|c|c|c|}
\hline \multirow[b]{2}{*}{ Variable } & \multirow[b]{2}{*}{ Group } & \multirow[b]{2}{*}{ Layer } & \multirow[b]{2}{*}{$\mathrm{T}_{0}$} & \multicolumn{3}{|c|}{$\mathrm{T}_{24}$} \\
\hline & & & & UC & AC & SC \\
\hline \multirow[t]{4}{*}{$\lg E$} & AR & Epithelium & $0(0-22)$ & $14(0-48)$ & $2(0-29)$ & $3(0-58)$ \\
\hline & & Subepithelium & $21(0-442)$ & $41(21-264)$ & $76(0-128)$ & $138(32-943)$ \\
\hline & C & Epithelium & $0(0-3)$ & $0(0-2)$ & 0 & $0(0-21)$ \\
\hline & & Subepithelium & $15(0-35)$ & $4(0-133)$ & $10(0-245)$ & $10(0-120)$ \\
\hline \multirow[t]{4}{*}{ BB1 } & AR & Epithelium & 0 & $0(0-1)$ & 0 & 0 \\
\hline & & Subepithelium & $0(0-4)$ & $9(0-144)$ & $88(22-223)^{*}$ & $25(5-350)^{\star}$ \\
\hline & C & Epithelium & 0 & 0 & 0 & 0 \\
\hline & & Subepithelium & $0(0-4)$ & $5(0-16)$ & $5(0-88)$ & $2(0-33)$ \\
\hline \multirow[t]{4}{*}{$\mathrm{MC}_{\mathrm{C}}$} & AR & Epithelium & 0 & $0(0-3)$ & 0 & 0 \\
\hline & & Subepithelium & $2(0-28)$ & $0(0-43)$ & $0(0-21)$ & $4(0-143)$ \\
\hline & C & Epithelium & 0 & 0 & $0(0-8)$ & $0(0-3)$ \\
\hline & & Subepithelium & $0(0-8)$ & $0(0-3)$ & $0(0-2)$ & $2(0-5)$ \\
\hline \multirow{4}{*}{$\mathrm{MC}_{\mathrm{TC}}$} & AR & Epithelium & $0(0-33)$ & $0(0-3)$ & $0(0-5)$ & 0 \\
\hline & & Subepithelium & $36(0-141)$ & $42(0-126)$ & $31(4-131)$ & $33(0-81)$ \\
\hline & C & Epithelium & $0(0-3)$ & $0(0-3)$ & $0(0-3)$ & $0(0-8)$ \\
\hline & & Subepithelium & $14(0-79)$ & $8(0-184)$ & $15(0-89)$ & $27(0-265)$ \\
\hline \multirow{4}{*}{$\mathrm{MC}_{\mathrm{T}}$} & AR & Epithelium & $1(0-10)$ & $8(0-55)$ & $0(0-22)$ & $0(0-24)$ \\
\hline & & Subepithelium & $111(0-622)$ & $161(28-351)$ & $139(25-323)$ & $74(0-326)$ \\
\hline & C & Epithelium & $0(0-19)$ & $0(0-13)$ & $8(0-31)$ & $9(0-36)$ \\
\hline & & Subepithelium & $127(8-203)$ & $56(10-140)$ & $151(0-414)$ & $110(0-300)$ \\
\hline
\end{tabular}

Definition of abbreviations: $\mathrm{AC}=$ allergen challenged right middle lobe; $\mathrm{AR}=$ allergic rhinitis patients; $\mathrm{C}=$ control subjects; $\mathrm{SC}=$ saline challenged right upper lobe; $\mathrm{UC}=$ unchallenged left lung.

Data are presented as median \pm range.

${ }^{*} \mathrm{p}<0.05$ (Wilcoxon's signed ranks test) 


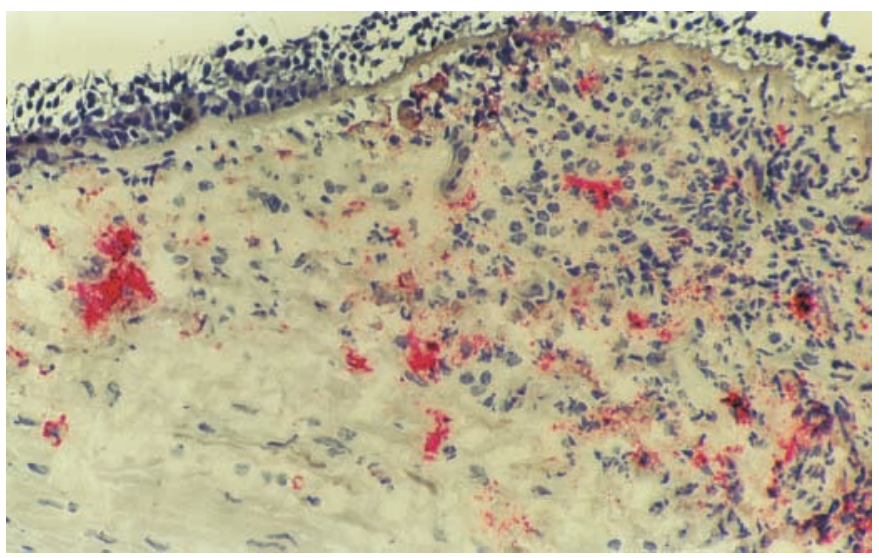

Figure 2. Bronchial biopsy specimens of a challenged allergic subject stained immunohistochemically for $\mathrm{BB} 1{ }^{+}$cells and counterstained with hematoxylin. Original mangnification $\times 200$.

with baseline numbers. At $\mathrm{T}_{24}$, however, the numbers of $\mathrm{MC}_{\mathrm{C}}$ $(\mathrm{p}=0.02)$ and $\mathrm{MC}_{\mathrm{TC}}(\mathrm{p}=0.04)$ cells in the nasal lamina propria of the allergic rhinitis patients were significantly decreased (Figures $5 \mathrm{a}$ and $5 \mathrm{~b}$ ). In contrast, the numbers of $\mathrm{MC}_{\mathrm{T}}$ and $\mathrm{IgE}^{+}$cells remained stable, whereas that of $\mathrm{BB} 1^{+}$cells was significantly increased $(p=0.01$; Figure $5 c)$. At $T_{24}$, the $\mathrm{BB}^{+}$cell number in the nasal subepithelium $(\mathrm{p}=0.01)$ and lamina propria $(\mathrm{p}=0.02)$ was significantly higher in allergic rhinitis patients than in controls. No significant increases from baseline were seen for $\mathrm{IgE}^{+}$, mast cell, or $\mathrm{BB}^{+}$cell numbers in healthy controls at either $\mathrm{T}_{1}$ or $\mathrm{T}_{24}$.

\section{Comparison of Cell Counts in Upper and Lower Airways}

At $\mathrm{T}_{0}, \mathrm{IgE}^{+}$cell numbers were significantly higher in nasal epithelium (Table 5) than in bronchial epithelium (Table 4) in the allergic rhinitis patients $(\mathrm{p}=0.02)$. In the controls, $\operatorname{IgE}^{+}$ cells were predominantly present in nasal epithelium as compared with bronchial epithelium $(\mathrm{p}=0.02)$, but cell counts were lower than in the allergic rhinitis subjects. In the subepithelium there was no difference between the number of $\operatorname{IgE}{ }^{+}$ cells in either the nose or the bronchi of the allergic rhinitis patients and control subjects. At $\mathrm{T}_{0}, \mathrm{BB}^{+}$cells could hardly be detected in either nasal or bronchial mucosa of the two study groups. At $\mathrm{T}_{24}$, however, the influx of $\mathrm{BB}^{+}$cells was much higher in the bronchial subepithelium than in the nasal subepithelium $(\mathrm{p}=0.04)$ of the allergic rhinitis patients, whereas no

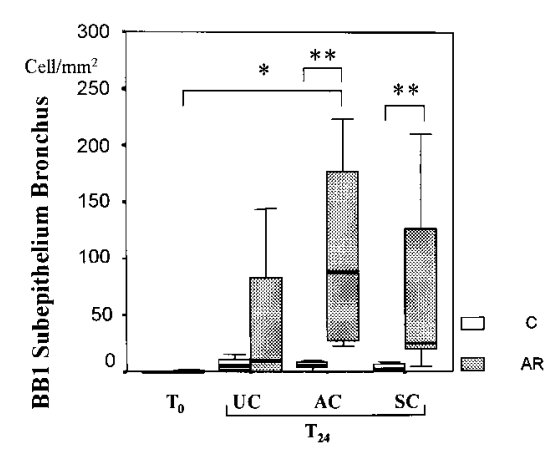

Figure 3. Number of $\mathrm{BB}^{+}$cells in subepithelial layer before $\left(\mathrm{T}_{0}\right)$ and $24 \mathrm{~h}\left(\mathrm{~T}_{24}\right)$ after SBP. AC = allergen challenged right middle lobe; $\mathrm{AR}=$ allergic rhinitis patients; $\mathrm{C}=$ control subjects; $\mathrm{SC}=$ saline challenged right upper lobe; UC = unchallenged left lung. Data are presented as median \pm range. ${ }^{*} p<0.05,{ }^{* *} p<0.01$.

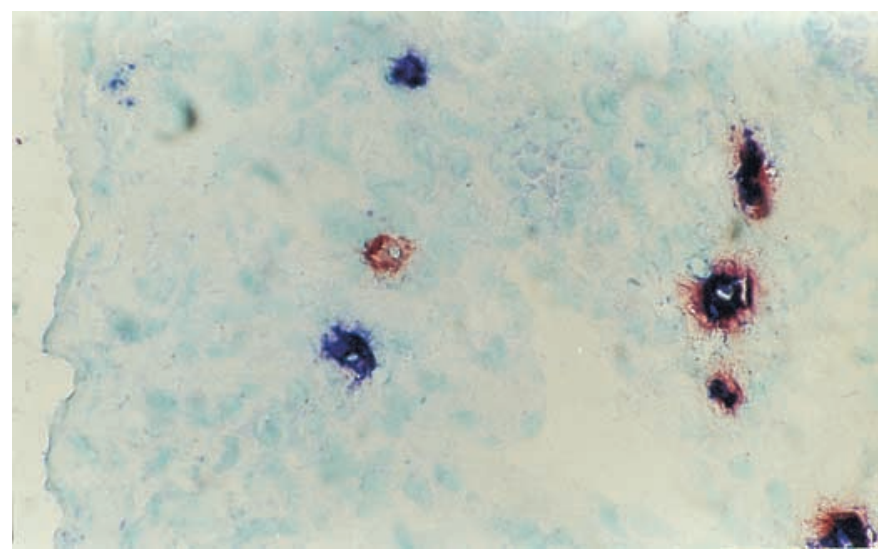

Figure 4. Nasal biopsy sections of an allergic subject showing immunoreactivity for mast cells at $T_{0}$. Counterstained with methyl green. Original magnification: $\times 400$.

difference was found in the control subjects. There was a clear difference in the relative distribution of chymase $^{+}$and tryptase $^{+}$cells between nasal and bronchial mucosa. In the bronchi, $\mathrm{MC}_{\mathrm{T}}$ was the predominant cell type $(74 \%$ in atopic subjects and $89 \%$ in controls), followed by $\mathrm{MC}_{\mathrm{TC}}(23 \%$ in atopic subjects versus $10 \%$ in controls) with almost no $\mathrm{MC}_{\mathrm{C}}$ cells ( $3 \%$ in atopic subjects versus $1 \%$ in controls). In contrast, $\mathrm{MC}_{\mathrm{TC}}$ cells were the most abundant cell type in the nose $(79 \%$ in atopic subjects and $89 \%$ in controls), followed by $\mathrm{MC}_{\mathrm{C}}$ cells (19\% in atopic subjects and 5\% in controls), and with very few $\mathrm{MC}_{\mathrm{T}}$ cells (3\% in both groups). At $\mathrm{T}_{24}$, the percentage of $\mathrm{MC}_{\mathrm{T}}$ cells increased significantly in the nasal subepithelium $(\mathrm{p}=$ 0.04 ) and to a lesser extent also in the bronchial subepithelium $(\mathrm{p}=0.2)$ of allergic rhinitis patients, at the expense of $\mathrm{MC}_{\mathrm{TC}}$ and $\mathrm{MC}_{\mathrm{C}}$ cells.

\section{DISCUSSION}

In this study, we were able to demonstrate changes in nasal mast cell and basophil numbers in nonasthmatic allergic rhinitis patients at $24 \mathrm{~h}$ after SBP. Furthermore, we found an influx of basophils into the bronchi of these nonasthmatic allergic rhinitis patients at $24 \mathrm{~h}$ after SBP. This occurred not only in challenged but also, albeit to a lesser extent, in saline challenged and unchallenged segments. In addition to these inflammation-related effects, we noticed a sustained decrease in $\mathrm{FEV}_{1}$ after SBP in subjects with allergic rhinitis. In a previous study, we demonstrated that SBP in allergic rhinitis patients induced eosinophilia in the blood and mucosal inflammation characterized by increased numbers of eosinophils, and of IL-5 ${ }^{+}$and eotaxin $^{+}$cells in both upper and lower airways (18). These data suggest a more generalized effect of local allergen deposition.

Granule secretion by mucosal mast cells, and the influx of basophils from blood into tissue, have been associated with disease activity in the upper and lower airways of patients with allergic rhinitis and asthma $(16,18,25-27)$. Since these two cell types are important for initiation and modulation of the allergic reaction $(11,14,15)$, we studied the dynamics of mast cells and basophils in the nasal mucosa after allergen provocation in a distant and "downstream" organ.

In the nasal mucosa, the numbers of chymase ${ }^{+}\left(\mathrm{MC}_{\mathrm{C}}\right)$ and tryptase $^{+} /$chymase $^{+}\left(\mathrm{MC}_{\mathrm{TC}}\right)$ mast cells decreased significantly, whereas the numbers of $\mathrm{BB} 1^{+}$cells increased significantly in allergic rhinitis patients at $24 \mathrm{~h}$ after SBP. In contrast to the 
TABLE 5. CELL NUMBERS IN NASAL SPECIMENS BEFORE ( $\left.T_{0}\right)$ AND $1 \mathrm{~h}\left(\mathrm{~T}_{1}\right)$ AND $24 \mathrm{~h}\left(\mathrm{~T}_{24}\right)$ AFTER SEGMENTAL BRONCHIAL PROVOCATION

\begin{tabular}{|c|c|c|c|c|c|}
\hline Variable & Group & Layer & $\mathrm{T}_{0}$ & $\mathrm{~T}_{1}$ & $\mathrm{~T}_{24}$ \\
\hline \multirow[t]{6}{*}{$\lg \mathrm{E}$} & AR & Epithelium & $34(0-140)$ & $13(0-215)$ & $6(0-42)$ \\
\hline & & Subepithelium & $106(9-1,211)$ & 157 (19-794) & $39(0-282)$ \\
\hline & & Lamina propria & $74(6-255)$ & 71 (14-192) & $46(5-88)$ \\
\hline & $\mathrm{C}$ & Epithelium & $4(0-20)$ & $1(0-11)$ & $1(0-24)$ \\
\hline & & Subepithelium & $32(10-55)$ & $29(3-168)$ & $16(0-34)$ \\
\hline & & Lamina propria & $14(6-40)$ & $12(8-34)$ & $10(2-28)$ \\
\hline \multirow[t]{6}{*}{ BB1 } & AR & Epithelium & 0 & $0(0-1)$ & 0 \\
\hline & & Subepithelium & $1(0-2)$ & $0(0-1)$ & $4(1-12)^{\star}$ \\
\hline & & Lamina propria & $1(0-5)$ & $2(0-3)$ & $7(3-14)^{*}$ \\
\hline & $\mathrm{C}$ & Epithelium & 0 & $0(0-1)$ & $0(0-1)$ \\
\hline & & Subepithelium & $1(0-1)$ & $1(0-1)$ & $1(0-9)$ \\
\hline & & Lamina propria & $1(0-5)$ & $1(0-4)$ & $2(0-10)$ \\
\hline \multirow[t]{6}{*}{$\mathrm{MC}_{\mathrm{C}}$} & AR & Epithelium & $0(0-16)$ & $0(0-6)$ & 0 \\
\hline & & Subepithelium & $29(8-86)$ & $22(11-45)$ & $15(0-179)$ \\
\hline & & Lamina propria & $18(5-48)$ & $11(3-21)$ & $3(1-25)^{*}$ \\
\hline & $\mathrm{C}$ & Epithelium & 0 & 0 & 0 \\
\hline & & Subepithelium & $9(0-55)$ & $6(2-59)$ & $5(1-19)$ \\
\hline & & Lamina propria & $4(1-27)$ & $5(1-47)$ & $3(0-15)$ \\
\hline \multirow[t]{6}{*}{$\mathrm{MC}_{\mathrm{TC}}$} & AR & Epithelium & $0(0-14)$ & $1(0-27)$ & $0(0-5)$ \\
\hline & & Subepithelium & 235 (54-694) & 449 (189-555) & $118(0-451)$ \\
\hline & & Lamina propria & $92(22-178)$ & $114(77-137)$ & $42(0-111)^{*}$ \\
\hline & $\mathrm{C}$ & Epithelium & $0(0-15)$ & 0 & 0 \\
\hline & & Subepithelium & $228(46-540)$ & $223(80-431)$ & $179(0-324)$ \\
\hline & & Lamina propria & $105(47-185)$ & $95(56-127)$ & $89(0-172)$ \\
\hline \multirow[t]{6}{*}{$M C_{T}$} & AR & Epithelium & $0(0-7)$ & $4(0-9)$ & $0(0-15)$ \\
\hline & & Subepithelium & $5(0-40)$ & $11(0-123)$ & $9(0-26)$ \\
\hline & & Lamina propria & $2(0-15)$ & $2(0-11)$ & $2(0-6)$ \\
\hline & $\mathrm{C}$ & Epithelium & 0 & 0 & $0(0-3)$ \\
\hline & & Subepithelium & $6(0-23)$ & $3(0-78)$ & $3(0-45)$ \\
\hline & & Lamina propria & $2(1-6)$ & $4(0-11)$ & $1(0-13)$ \\
\hline
\end{tabular}

Definition of abbreviations: $\mathrm{AR}=$ allergic rhinitis patients; $\mathrm{C}=$ control subjects.

Data are presented as median \pm range.

${ }^{*} p<0.05$ (Wilcoxon's signed ranks test).

changes found in the nose, the number of mast cells in the bronchial subepithelium, which are predominantly tryptase ${ }^{+}$ $(24,28,29)$, did not change significantly after SBP. A possible explanation for the relatively stable number of tryptase ${ }^{+}$cells in the nasal and bronchial mucosae could be the influx of tryptase $^{+}$basophils from the peripheral blood into the bronchial mucosa (30).

Discrepancies in mast cell counts in different studies, probably caused by different methods for detecting of mast cells, have led to various opinions about mast cell dynamics. Transmucosal migration of mast cells into the epithelium has been suggested as a possible mechanism for an increase in epithelial mast cells after allergen exposure $(5,31)$. Degranulation has been proposed and demonstrated by other authors, and could also contribute to changes in mast cell numbers in the nasal and bronchial mucosae $(10,26,32,33)$. Immunohistochemical analysis of mast cells is hampered by the lack of a universal mast cell membrane-associated marker. In our study we found no indication of a redistribution of mast cells in nasal and bronchial mucosae at either an early $\left(\mathrm{T}_{1}\right)$ or a late $\left(\mathrm{T}_{24}\right)$ time point. Therefore, degranulation is a more likely mechanism for the sudden decrease in $\mathrm{MC}_{\mathrm{C}}$ and $\mathrm{MC}_{\mathrm{TC}}$ cells in the nasal lamina propria of allergic rhinitis patients after SBP, whereas the number of $\mathrm{IgE}^{+}$cells remains stable. Degranulation of mast cells in the nose after SBP occurred at a relatively late time point as compared with that found in experiments after nasal allergen challenge. KleinJan and coworkers demonstrated an increase in the number of basophils and a reduction in mast cell numbers in nasal mucosa of allergic rhinitis subjects within $1 \mathrm{~h}$ after nasal allergen provocation (28). In our study, no changes in the number of nasal mast cells or baso- phils were seen at $1 \mathrm{~h}$ after SBP. At $\mathrm{T}_{24}$, however, more than $50 \%$ of $\mathrm{MC}_{\mathrm{TC}}$ cells in the nasal lamina propria of allergic rhinitis patients (as compared with only $10 \%$ in controls) had lost their granule contents, which is in accordance with findings during natural exposure (26). Lozewicz and Wagenmann have shown that unilateral nasal allergen challenge results in an immediate reduction in the number of stainable mast cells (34) and in a delayed increase in basophil numbers and histamine production in the contralateral unstimulated nostril (35). Lozewicz and Wagenmann speculated that a neural reflex mechanism was most likely to contribute to mast cell degranulation in the unchallenged nostril. The delayed effect on nasal mucosal mast cells that we see in our model, however, is more suggestive of a systemic allergic response.

In allergic rhinitis patients, we found a decreased number of basophils in the peripheral blood at $24 \mathrm{~h}$ after SBP. The decrease in circulating basophils at this time point could have been the result of active migration and redistribution of these cells from the blood to the affected tissue (16). Moreover, we detected increased expression of IL-5 in the serum of allergic rhinitis patients after SBP, which suggests that a systemic allergic response is triggered. Cytokines such as IL-5, but also IL-1, IL-3, granulocyte-macrophage colony-stimulating factor (GM-CSF), stem-cell factor, nerve growth factor, histaminereleasing factor, and interferon- $\gamma$ are capable of priming basophils (36). Both IL-3 and GM-CSF were undetectable in serum samples in our study (data not shown). Comparable serum IL-5 results have been demonstrated in patients with allergic asthma after bronchial allergen provocation (37) and natural exposure to allergen (38). Furthermore, nasal provocation with methacholine in asthmatic patients with rhinitis resulted in an 

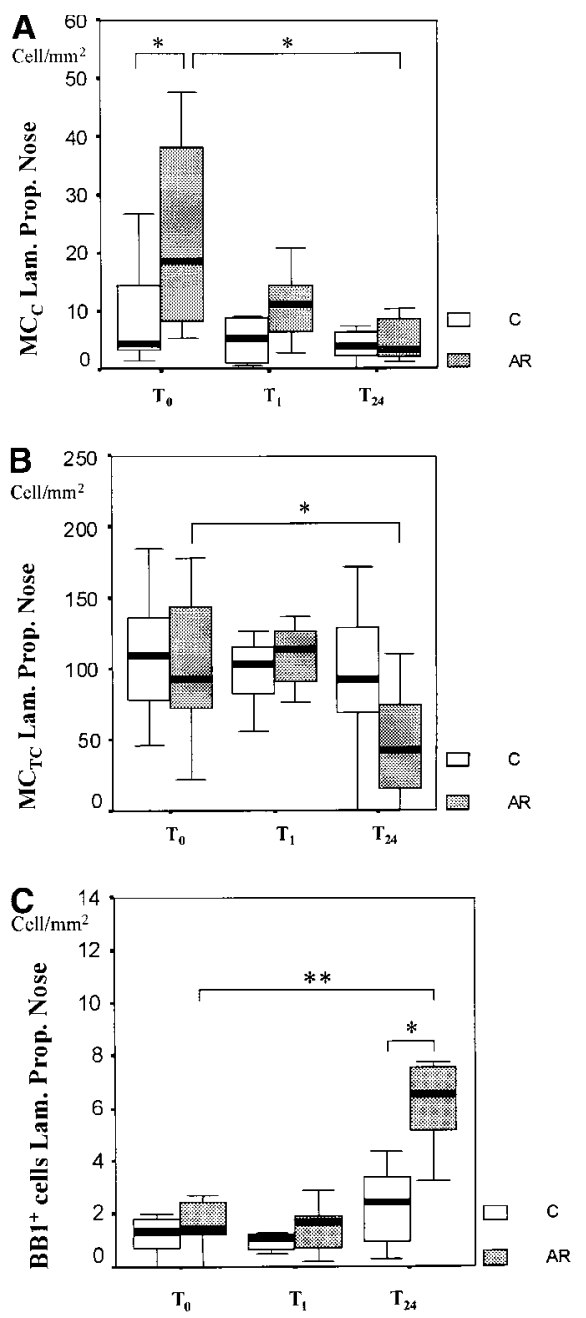

Figure 5. Number of $\mathrm{MC}_{\mathrm{C}}(A), \mathrm{MC}_{\mathrm{TC}}(B)$, and $\mathrm{BB} 1^{+}(C)$ cells in the nasal lamina propria before $\left(\mathrm{T}_{0}\right)$ and at $1 \mathrm{~h}\left(\mathrm{~T}_{1}\right)$ and $24 \mathrm{~h}\left(\mathrm{~T}_{24}\right)$ after SBP. $\mathrm{AR}=$ allergic rhinitis patients; $\mathrm{C}=$ control subjects. Data are presented as median \pm range. ${ }^{\star} p<0.05,{ }^{* *} p<0.01$.

increase in lower airway resistance that could be blocked by premedication of the nasal mucosa with phenylephrine (39). This is also suggestive of a systemic effect of inflammatory mediators in the induction of lower airway resistance. Another possible interaction mechanism could be systemic allergen absorption, as was suggested by Kontou-Karakitsos and colleagues in the early 1970s (40). However, the allergen we used, grass pollen, has a much higher molecular weight than the antigen fragments used in the peanut extract in their study. Therefore, we find it less plausible that grass pollen particles cross the mucosal barrier and merge in the blood.

It is highly unlikely that the methodologic approach used in our study would contribute to a systemic allergic response. Bronchoscopy and biopsy per se do not result in generalized bronchial inflammation (41). To minimize the intraluminal spread of antigen from the allergen-challenged segment to other segments, the bronchoscope in our study was held in the wedged position. It is also very unlikely that allergen spilled into the nose after SBP, since bronchoscopy was performed via the oral route and did not lead to excessive coughing. This is supported by a small study that addressed the issue of crosscontamination of the nose and lungs with a radioactive tracer (42). In this pilot study, a radionuclide was placed bronchoscopically into the bronchial tree in four patients, and was still clearly visible in the same position after $24 \mathrm{~h}$, suggesting that contamination of the nose through intraluminal spread is unlikely to take place (42).

On the basis of our results, we hypothesize that allergic rhinitis patients without bronchial hyperresponsiveness can express "asthma-like" symptoms and inflammation. However, the dose of allergen required to initiate an allergic response in the bronchi is probably higher in allergic rhinitis patients than in patients with clinical asthma. Apparently, such a dose is not encountered during natural exposure to allergen. Moreover, other factors, such as the type of inhalant allergy and the duration and severity of exposure, are important in this context (43). We also found that SBP influences the number of stainable mast cells and basophils in the upper airways of allergic rhinitis patients. We speculate that enhanced production of inflammatory mediators at the site of allergen provocation leads to a more generalized effect on metachromatic cells throughout the respiratory system and the blood.

Acknowledgment: The authors thank the allergology department, lung function laboratory, and clinical chemistry laboratory, and coworkers in the pulmonary and ear, nose and throat research departments of the Erasmus University Medical Center Rotterdam for their valuable participation in this study, and Mrs. Sandra Reijnhart for editing the manuscript.

\section{References}

1. The International Study of Asthma and Allergies in Childhood (ISAAC) Steering Committee. Worldwide variation in prevalence of symptoms of asthma, allergic rhinoconjunctivitis, and atopic eczema: ISAAC. Lancet 1998;351:1225-1232.

2. Howarth PH. Is allergy increasing?-early life influences. Clin Exp Allergy 1998;28:2-7.

3. Panhuysen CI, Meyers DA, Postma DS, Bleecker ER. The genetics of asthma and atopy. Allergy 1995;50:863-869.

4. Bousquet J, Chanez P, Lacoste JY, Barneon G, Ghavanian N, Enander I, Venge P, Ahlstedt S, Simony-Lafontaine J, Godard P, et al. Eosinophilic inflammation in asthma. N Engl J Med 1990;323:1033-1039.

5. Bentley AM, Jacobson MR, Cumberworth V, Barkans JR, Moqbel R, Schwartz LB, Irani AM, Kay AB, Durham SR. Immunohistology of the nasal mucosa in seasonal allergic rhinitis: increases in activated eosinophils and epithelial mast cells. J Allergy Clin Immunol 1992;89: 877-883.

6. Bradley BL, Azzawi M, Jacobson M, Assoufi B, Collins JV, Irani AM, Schwartz LB, Durham SR, Jeffery PK, Kay AB. Eosinophils, T-lymphocytes, mast cells, neutrophils, and macrophages in bronchial biopsy specimens from atopic subjects with asthma: comparison with biopsy specimens from atopic subjects without asthma and normal control subjects and relationship to bronchial hyperresponsiveness. $J$ Allergy Clin Immunol 1991;88:661-674.

7. Chanez P, Vignola AM, Vic P, Guddo F, Bonsignore G, Godard P, Bousquet J. Comparison between nasal and bronchial inflammation in asthmatic and control subjects. Am J Respir Crit Care Med 1999; 159:588-595.

8. Foresi A, Leone C, Pelucchi A, Mastropasqua B, Chetta A, D'Ippolito R, Marazzini L, Olivieri D. Eosinophils, mast cells, and basophils in induced sputum from patients with seasonal allergic rhinitis and perennial asthma: relationship to methacholine responsiveness. J Allergy Clin Immunol 1997:100:58-64.

9. Sedgwick JB, Calhoun WJ, Gleich GJ, Kita H, Abrams JS, Schwartz LB, Volovitz B, Ben-Yaakov M, Busse WW. Immediate and late airway response of allergic rhinitis patients to segmental antigen challenge: characterization of eosinophil and mast cell mediators. Am Rev Respir Dis 1991;144:1274-1281.

10. Djukanovic R, Lai CK, Wilson JW, Britten KM, Wilson SJ, Roche WR, Howarth PH, Holgate ST. Bronchial mucosal manifestations of atopy: a comparison of markers of inflammation between atopic asthmatics, atopic nonasthmatics and healthy controls. Eur Respir J 1992;5:538-544.

11. Peebles RS Jr, Togias A. Role of mast cells and basophils in rhinitis. Chem Immunol 1995;62:60-83.

12. Bradding P, Okayama Y, Howarth PH, Church MK, Holgate ST. Heterogeneity of human mast cells based on cytokine content. J Immunol 1995;155:297-307.

13. He S, Walls AF. Human mast cell chymase induces the accumulation of 
neutrophils, eosinophils and other inflammatory cells in vivo. $\mathrm{Br} \mathrm{J}$ Pharmacol 1998;125:1491-1500.

14. Redrup AC, Howard BP, MacGlashan DW Jr, Kagey-Sobotka A, Lichtenstein LM, Schroeder JT. Differential regulation of IL-4 and IL-13 secretion by human basophils: their relationship to histamine release in mixed leukocyte cultures. J Immunol 1998;160:1957-1964.

15. Schroeder JT, MacGlashan DW Jr, Kagey-Sobotka A, White JM, Lichtenstein LM. IgE-dependent IL-4 secretion by human basophils: the relationship between cytokine production and histamine release in mixed leukocyte cultures. J Immunol 1994;153:1808-1817.

16. Shute J. Basophil migration and chemotaxis. Clin Exp Allergy 1992;22: 321-323.

17. Bascom R, Wachs M, Naclerio RM, Pipkorn U, Galli SJ, Lichtenstein LM. Basophil influx occurs after nasal antigen challenge: effects of topical corticosteroid pretreatment. J Allergy Clin Immunol 1988;81:580-589.

18. Naclerio RM, Proud D, Togias AG, Adkinson NF, Jr, Meyers DA, Kagey-Sobotka A, Plaut M, Norman PS, Lichtenstein LM. Inflammatory mediators in late antigen-induced rhinitis. $N$ Engl J Med 1985; 313:65-70.

19. Iliopoulos O, Baroody FM, Naclerio RM, Bochner BS, Kagey-Sobotka A, Lichtenstein LM. Histamine-containing cells obtained from the nose hours after antigen challenge have functional and phenotypic characteristics of basophils. J Immunol 1992;148:2223-2228.

20. Braunstahl GJ, KleinJan A, Overbeek SE, Prins JB, Hoogsteden HC, Fokkens WJ. Segmental bronchial provocation induces nasal inflammation in allergic rhinitis patients. Am J Respir Crit Care Med 2000; 161:2051-2057.

21. McEuen AR, Buckley MG, Compton SJ, Walls AF. Development and characterization of a monoclonal antibody specific for human basophils and the identification of a unique secretory product of basophil activation. Lab Invest 1999;79:27-38.

22. Hargreave FE, Ramsdale EH, Sterk PJ, Juniper EF. Advances in the use of inhalation provocation tests in clinical evaluation. Chest 1985;87: 32S-35S.

23. Fokkens WJ, Vroom TM, Gerritsma V, Rijntjes E. A biopsy method to obtain high quality specimens of nasal mucosa. Rhinology 1988;26: 293-295.

24. KleinJan A, Godthelp T, Blom HM, Fokkens WJ. Fixation with Carnoy's fluid reduces the number of chymase-positive mast cells: not all chymase-positive mast cells are also positive for tryptase. Allergy 1996; 51:614-620.

25. Djukanovic R, Wilson JW, Britten KM, Wilson SJ, Walls AF, Roche WR, Howarth PH, Holgate ST. Quantitation of mast cells and eosinophils in the bronchial mucosa of symptomatic atopic asthmatics and healthy control subjects using immunohistochemistry. Am Rev Respir Dis 1990;142:863-871.

26. Fokkens WJ, Godthelp T, Holm AF, Blom H, Mulder PG, Vroom TM, Rijntjes E. Dynamics of mast cells in the nasal mucosa of patients with allergic rhinitis and non-allergic controls: a biopsy study. Clin Exp Allergy 1992;22:701-710.

27. Maruyama N, Tamura G, Aizawa T, Ohrui T, Shimura S, Shirato K, Takishima T. Accumulation of basophils and their chemotactic activity in the airways during natural airway narrowing in asthmatic individuals. Am J Respir Crit Care Med 1994;150:1086-1093.

28. Kleinjan A, McEuen AR, Dijkstra MD, Buckley MG, Walls AF,
Fokkens WJ. Basophil and eosinophil accumulation and mast cell degranulation in the nasal mucosa of patients with hay fever after local allergen provocation. J Allergy Clin Immunol 2000;106:677-686.

29. Weidner N, Austen KF. Heterogeneity of mast cells at multiple body sites: fluorescent determination of avidin binding and immunofluorescent determination of chymase, tryptase, and carboxypeptidase content. Pathol Res Pract 1993;189:156-162.

30. Li L, Li Y, Reddel SW, Cherrian M, Friend DS, Stevens RL, Krilis SA Identification of basophilic cells that express mast cell granule proteases in the peripheral blood of asthma, allergy, and drug-reactive patients. J Immunol 1998;161:5079-5086.

31. Juliusson S, Pipkorn U, Karlsson G, Enerback L. Mast cells and eosinophils in the allergic mucosal response to allergen challenge: changes in distribution and signs of activation in relation to symptoms. $J$ Allergy Clin Immunol 1992;90:898-909.

32. Gomez E, Corrado OJ, Baldwin DL, Swanston AR, Davies RJ. Direct in vivo evidence for mast cell degranulation during allergen-induced reactions in man. J Allergy Clin Immunol 1986;78:637-645.

33. Kawabori S, Okuda M, Unno T. Mast cells in allergic nasal epithelium and lamina propria before and after provocation: an electron microscopic study. Clin Allergy 1983;13:181-189.

34. Lozewicz S, Gomez E, Chalstrey S, Gatland D, Davies RJ. Time course of cellular infiltration in the nasal mucosa during the immediate allergic reaction. Int Arch Allergy Appl Immunol 1991;95:273-277.

35. Wagenmann M, Baroody FM, Cheng CC, Kagey-Sobotka A, Lichtenstein LM, Naclerio RM. Bilateral increases in histamine after unilateral nasal allergen challenge. Am J Respir Crit Care Med 1997;155: 426-431.

36. Bochner BS. Systemic activation of basophils and eosinophils: markers and consequences. J Allergy Clin Immunol 2000;106:292-302.

37. van der Veen MJ, Van Neerven RJ, De Jong EC, Aalberse RC, Jansen HM, van der Zee JS. The late asthmatic response is associated with baseline allergen-specific proliferative responsiveness of peripheral $\mathrm{T}$ lymphocytes in vitro and serum interleukin-5. Clin Exp Allergy 1999; 29:217-227.

38. Becky Kelly EA, Busse WW, Jarjour NN. Inhaled budesonide decreases airway inflammatory response to allergen. Am J Respir Crit Care Med 2000;162:883-890.

39. Littell NT, Carlisle CC, Millman RP, Braman SS. Changes in airway resistance following nasal provocation. Am Rev Respir Dis 1990;141: $580-583$.

40. Kontou-Karakitsos K, Salvaggio JE, Mathews KP. Comparative nasal absorption of allergens in atopic and nonatopic subjects. $J$ Allergy Clin Immunol 1975;55:241-248.

41. Jarjour NN, Peters SP, Djukanovic R, Calhoun WJ. Investigative use of bronchoscopy in asthma. Am J Respir Crit Care Med 1998;157:692-697.

42. Bardin PG, Van Heerden BB, Joubert JR. Absence of pulmonary aspiration of sinus contents in patients with asthma and sinusitis. J Allergy Clin Immunol 1990;86:82-88.

43. Witteman AM, Sjamsoedin DH, Jansen HM, van der Zee JS. Differences in nonspecific bronchial responsiveness between patients with asthma and patients with rhinitis are not explained by type and degree of inhalant allergy. Int Arch Allergy Immunol 1997;112:65-72. 